Article

\title{
Specific Cytotoxic Effects of Parasporal Crystal Proteins Isolated from Native Saudi Arabian Bacillus thuringiensis Strains against Cervical Cancer Cells
}

\author{
Mourad A. M. Aboul-Soud ${ }^{1,2, *}$, , Mohammed Z. Al-Amri ${ }^{1}$, Ashok Kumar ${ }^{3}$, \\ Yazeed A. Al-Sheikh ${ }^{1}$, Abdelkader E. Ashour ${ }^{4, \S}$ and Talat A. El-Kersh ${ }^{1}$ \\ 1 Chair of Medical and Molecular Genetics Research, Department of Clinical Laboratory Sciences, \\ College of Applied Medical Sciences, King Saud University, P.O. Box 10219, Riyadh 11433, Saudi Arabia; \\ mohd.zain2@hotmail.com (M.Z.A.-A.); yalsheikh@KSU.EDU.SA (Y.A.A.-S.); \\ talatkersh@yahoo.com (T.A.E.-K.) \\ 2 Cairo University Research Park, Cairo University, Giza 12613, Egypt \\ 3 Vitiligo Research Chair, College of Medicine, King Saud University, P.O. Box 10219, Riyadh 11433, \\ Saudi Arabia; aknirankari@gmail.com \\ 4 Department of Pharmacology and Toxicology, College of Pharmacy, King Saud University, P.O. Box 2457, \\ Riyadh 11451, Saudi Arabia; aeashour@gmail.com \\ * Correspondence: maboulsoud@ksu.edu.sa; Tel.: +966114698617; Fax: +966114693738 \\ $\S$ Present address: Department of Basic Medical Sciences,t Kulliyyah of Medicine, International Islamic \\ University Malaysia, 25200 Kuantan, Pahang Darul Makmur, Malaysia; the author's entire contribution \\ towards this paper was solely during his term at King Saud University.
}

Received: 3 January 2019; Accepted: 21 January 2019; Published: 31 January 2019

check for updates

\begin{abstract}
Currently, global efforts are being intensified towards the discovery of local Bacillus thuringiensis (Bt) isolates with unique anticancer properties. Parasporins (PS) are a group of Bt non-insecticidal crystal proteins with potential and specific in vitro anticancer activity. However, despite the significant therapeutic potential of PS-producing Bt strains, our current knowledge on the effects of these proteins is limited. Hence, the main objective of this study was to screen Bt-derived parasporal toxins for cytotoxic activities against colon (HT-29) and cervical (HeLa) cancerous cell lines. Nine non-larvicidal and non-hemolytic Bt strains, native to Saudi Arabia, were employed for the isolation of their parasporal toxins. $16 \mathrm{~S} \mathrm{rDNA}$ sequencing revealed a $99.5 \%$ similarity with a reference $\mathrm{Bt}$ strain. While PCR screening results indicated the absence of selected Cry (Cry4A, Cry $4 B, C r y 10$ and Cry11), Cyt (Cyt1 and Cyt2) and PS (PS2, PS3 and PS4) genes, it concluded presence of the PS1 gene. SDS-PAGE analysis revealed that proteolytically-cleavaged PS protein profiles exhibit patterns resembling those observed with PS1Aa1, with major bands at $56 \mathrm{kDa}$ and $17 \mathrm{kDa}(\mathrm{Bt} 7)$, and $41 \mathrm{kDa}$ and $16 \mathrm{kDa}(\mathrm{Bt} 5)$. Solubilized and trypsinized PS proteins from all Bt strains exhibited a marked and dose-dependent cytotoxicity against HeLa cancerous cells but not against HT-29 cells. IC 50 values ranged from 3.2 (Bt1) to 14.2 (Bt6) with an average of $6.8 \mu \mathrm{g} / \mathrm{mL}$. The observed cytotoxicity of PS proteins against HeLa cells was specific as it was not evident against normal uterus smooth muscle cells. RT-qPCR analysis revealed the overexpression of caspase 3 and caspase 9 by 3.7, and 4.2 folds, respectively, indicative of the engagement of intrinsic pathway of apoptosis. To the best of our knowledge, this is the first report exploring and exploiting the versatile repertoire of Saudi Arabian environmental niches for the isolation of native and possibly novel Saudi Bt strains with unique and specific anticancer activity. In conclusion, native Saudi Bt-derived PS proteins might have a potential to join the arsenal of natural anticancer drugs.
\end{abstract}

Keywords: Bacillus thuringiensis; parasporin; $\delta$-endotoxin; non-insecticidal inclusions; in vitro cytotoxicity; apoptosis 


\section{Introduction}

Cancer is one of the leading causes of death worldwide and therefore it poses a major global public health concern. In 2018, a striking rise in global cancer burden has been reported with 18.1 million newly diagnosed cases, 9.6 million mortalities and 43.8 million people 5 -year survival rate compared to only $12.4,7.6$ and 28 million people in 2008 , respectively. In 2030, it is projected that these figures will continue to rise to an alarming 26.4 million newly diagnosed cases and 17 million cancer-related deaths [1]. Worldwide, lung, breast and colorectal cancers account for one third of cancer incidence and mortality burden, are classified in the top three highly prevalent cancer types, and ranked within the top five in terms of death rates (1st, 5 th and 2nd, respectively). According to gender, colorectal cancer (CRC) ranks third (10.9\%) in terms of incidence in males, whereas breast cancer (BC) ranks first in women $(24.2 \%)$. Cervical cancer ranks fourth for both. Cervical cancer leads the race for both incidence $(6.6 \%)$ and mortality $(7.5 \%)$ being ranked fourth for both in women [1]. In Saudi Arabia, cancer prevalence is also affected by gender, with CRC (13.3\%) and BC (25.8\%) are the most predominant types in men and women, respectively [2]. By the year 2030, it has been predicted that the CRC incidence in Saudi Arabia would increase four-fold in both genders. Moreover, it is estimated that by year 2025, incidence and mortality rates will significantly rise by $350 \%$ and $160 \%$, respectively [3]. Therefore, countries should be prepared to face the challenge of a foreseeable increase in cancer burden. This is mainly attributed to the population growth, adoption of modern lifestyles and its associated risk factors (e.g., tobacco smoking, increased consumption of meat and adopting sedentary way of life that lead to an increase in the body mass index and obesity) and aging of the population [4]. Despite the fact that conventional anticancer therapies (i.e., surgical resection, radiotherapy and chemotherapy) are effective in the management of patients, they are however ineffective in approximately $50 \%$ of malignancy cases. Unfortunately, currently employed synthetic cytotoxic drugs can be associated with a range of side effects including neutropenia, oral ulceration, diarrhea, hair loss, and nerve and kidney damage [5]. Therefore, substantial efforts are currently being focused on the development of novel and natural alternative therapeutic techniques for the efficient targeting of tumors.

Bacillus thuringiensis (Bt) is a Gram-positive spore-forming bacterium that is uniquely characterized by the production of proteinaceous crystalline parasporal inclusions in sporulating cells. Insecticidal Bt produces parasporal inclusions (proteins) collectively known as $\delta$-endotoxin. These parasporal inclusions are encoded by a family of $\mathrm{Cry}$ and $\mathrm{Cyt}$ genes [6]. For decades, these Bt parasporal proteins have been successfully employed as biological control agents [7] and they are currently classified and named based on their protein identities according to norms provided by the Bt $\delta$-endotoxin nomenclature committee [8,9], whereby ensuring that closely related toxins are ranked together. The economic importance and long use in biological pest management programs of Cry proteins has stirred a significant amount of work primarily focused on the elucidation of their mode-of-action [10]. Therefore, the mode-of-action of $\delta$-endotoxin proteins is thought to involve: (i) solubilization of the crystal in the insect's midgut, (ii) proteolytic activation of the protoxin by midgut proteases, (iii) binding of the Cry toxin to midgut glycoprotein receptors, which are located at the surface of the apical brush border membrane of epithelial columnar cells, and (iv) insertion of the toxin into the apical membrane, where it creates pores (ion channels) and eventually kills susceptible insects [11].

Research reports from our lab and from others concluded that Bt isolates with non-insecticidal Cry proteins are more prevalently distributed than insecticidal ones in natural environmental niches, accounting for more than $90 \%$ of the natural populations from soils and phylloplanes [12,13]. This observation has stimulated a new line of research questioning whether the non-insecticidal Cry proteins possess some as yet unidentified novel biological functions. These efforts have subsequently revealed that Cry proteins produced by non-insecticidal Bt isolates exhibit unique cytocidal activities against human cancer cells [14]. This anticancer activity has been attributed to the presence of a 
new family of Bt parasporal inclusions designated as parasporin (PS) [15]. PS has been defined as "Bacillus thuringiensis and related bacterial parasporal proteins that are non-hemolytic but capable of preferentially killing cancerous cells" [16]. However, it has to be noted that Cry and PS terms are not mutually exclusive as some PS proteins may possess both insecticidal and cancer cytocidal activities. PS was first identified as a human leukemic cell-recognizing parasporal protein [15]. Similar to Cry toxins, PS molecules are synthesized as nascent protoxins that require proteoloytic processing to exert its full cytotoxic potential [13]. However, despite the structural resemblance of PS proteins with Cry toxins, they only exhibit less than $25 \%$ of amino acid sequence homology with them, thus they require a distinct classification system. Accordingly, the Committee of Parasporin Classification and Nomenclature (http:/ / parasporin.fitc.pref.fukuoka.jp/) has been established to construct a taxonomically-sound quaternary rank nomenclature systems based on the amino acid identity, similar to that followed with Cry toxins [17]. Initially, there were six first-rank categories of PS (PS1 to PS4) [17], but soon this was updated to include two new subgroups (PS5 and PS6) [18,19]. Currently immense research efforts are being devoted to the discovery of novel classes of PS proteins. The abundance of these bacilli in nature and their selectivity have made them potential candidates for cancer treatment. However, literature on the in vivo effect of these proteins is scarce. Since different Bt strains produce different cytotoxic proteins with wide variations in their anticancer effect and mechanism-of-action, further investigations are necessary and their effect in vivo must be well established before they can be used in clinical trials. Many countries including Saudi Arabia (our research team) are continuing to screen and isolate novel strains in natural environments to apply for biological pest management programs whereby reducing insect resistance to $\mathrm{Bt}[12,20-23]$. Moreover, global efforts are currently being intensified towards the discovery of local Bt isolates with unique anticancer properties [13,19,24-26].

In the light of the potential application of these ubiquitous proteins in cancer therapy, this study was undertaken to characterize nine new non-larvicidal and non-hemolytic Bt isolates collected from various regions in Saudi Arabia according to: (i) colony and crystal morphology, (ii) protein profile of the crystalline parasporal inclusions, (iii) screening for presence of Cry, Cyt and PS genes by PCR, (iv) screening for in vitro cytotoxic activities against two selected cancerous cell lines; viz., colon (HT-29) and cervical (HeLa), and (v) mechanism of killing.

\section{Results}

\subsection{Phase Contrast and Electron Microscopy}

Colonies of the recovered nine Bt isolates on nutrient agar supplemented (NAS) medium appeared as circular, scalloped-edged, non-pigment, off-white with irregular margins and slightly centered (data not shown). Colonies were tentatively classified into three groups (A to C). A: off-white, round, mucoid, slightly raised center; B: off-white, shiny, little-raised center, and irregular margin, and C: off-white, round, slightly raised center. The ratios for colonial morphology of the Bt strains were type $\mathrm{A}=$ $55.56 \%, \mathrm{~B}=33.33 \%$ and $\mathrm{C}=11.11 \%$. Phase contrast microscopy revealed that all Bt strains shared many morphological characteristics in cell chains arrangement, ellipsoidal shape of spores, and sporangia, in agreement with our previously published data [27]. The nine Bt isolates under investigation were classified into four classes according to diverse morphological characteristics of its parasporal crystals, viz., spherical, hexagonal, bi-pyramidal and ovoid (Figure 1). It is worth noting that spherical and hexagonal crystals were the most predominant types among the studied $\mathrm{Bt}$ isolates, conforming to our recently published report [28]. To confirm the above observed crystal shape of selected Bt isolates, some isolates were also examined by scanning electron microscopy (SEM). For example, Bt6 (M268) examination under SEM clearly revealed the typical hexagonal attached crystal parasporal inclusions with better resolution and clarity (Figure 2). 


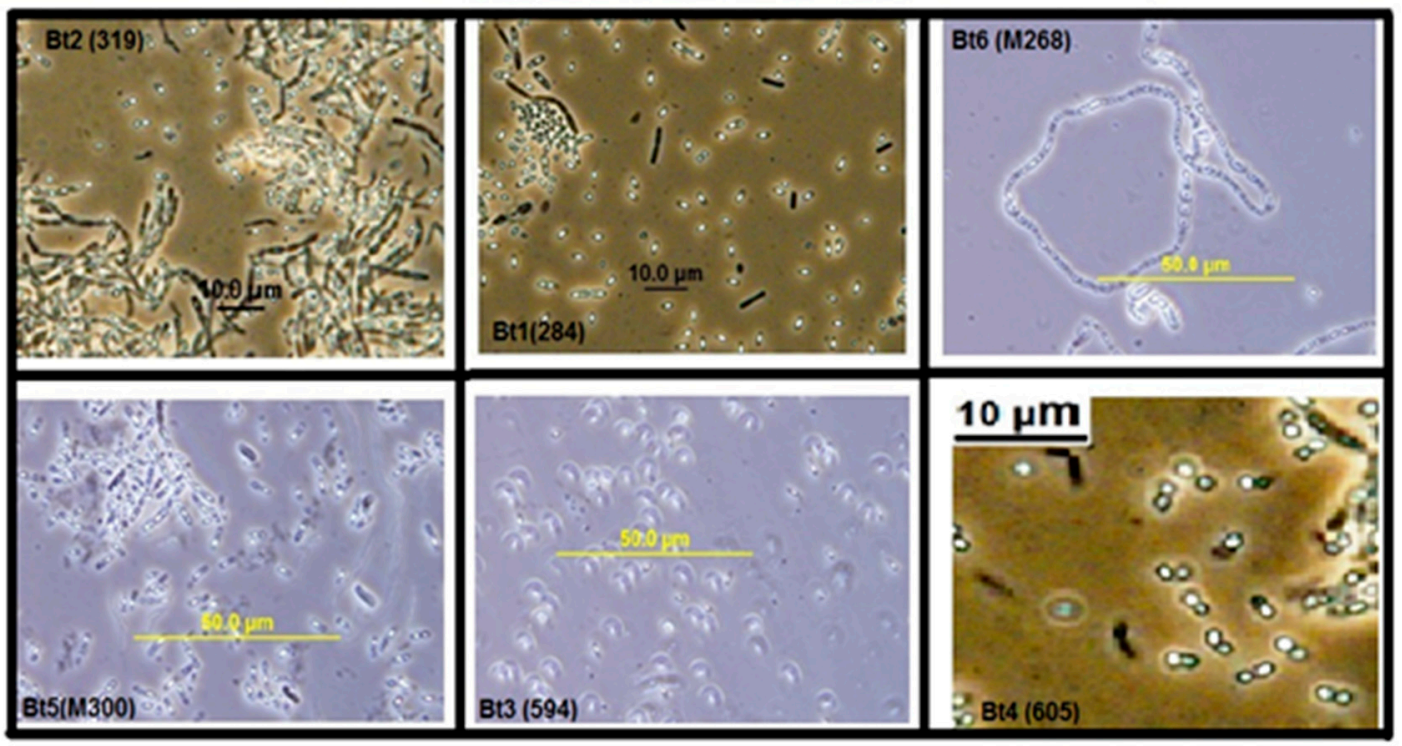

Figure 1. Phase contrast micrographs of some native Bt isolates. Morphology of parasporal crystals from Bt1, Bt2, Bt3, Bt4, Bt5, Bt6 is bi-pyramidal, spherical, small bi-pyramidal, attached crystals, ovoid and hexagonal, respectively. Within 'parentheses' are their respective original identification numbers.

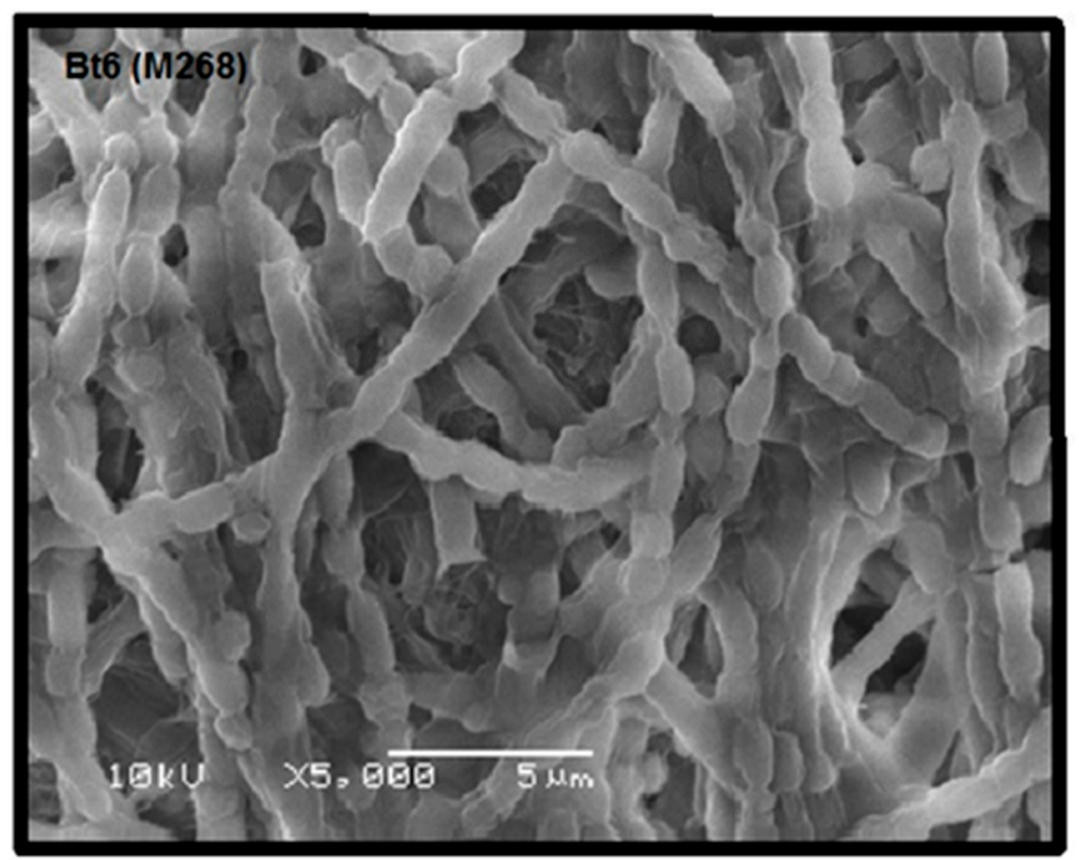

Figure 2. Scanning electron micrograph of Bt6 isolate at magnification of $5000 \times$ showing characteristic hexagonal attached crystals (arrow head).

\subsection{Biochemical and $16 S$ Molecular Typing of Isolated Bt Strains}

All Bt isolates were negative for $\mathrm{H}_{2} \mathrm{~S}=$ Sodium thiosulfate, URE = Urea, IND = L-tryptophan, SOR $=$ D-sorbitol, RHA = L-rhamnose and MEL $=$ D-melibiose. For SAC (Sucrose) there were three positives (Bt1, 4 and 5) and the other six were negative. For AMY (starch hydrolysis), all strains were positive except Bt6 and 8. For VP (Sodium pyruvate), six isolates (Bt1, 2, 5, 6, 8 and 9) were positive, whereas the other three were negative. For CIT (Citrate), there were six positives, with the exception for Bt4, 6 and 8. As for OX (Oxidase), all were positive except Bt3. With respect to MOT (Motility), four were motile (Bt1, 3, 4 and 5) while the other four were non-motile. All strains were positive for 
arginine dihydrolase (ADH) activity with the exception of Bt3, 6 and 8 (Table 1). As for 16S typing, target amplicon bands ( $1550 \mathrm{bp})$ were detected by agarose gel electrophoresis, for all tested Bt strains and reference strains (Bti-H14 and B. cereus) before being sequenced (data not shown). Phylogenetic data analysis of the obtained $16 S \mathrm{rDNA}$ gene sequences indicated that the nine tested isolates shared a high degree of homology (up to $99.5 \%$ ) to Bti-H14 reference strain, which is in agreement with our previously published data [28].

Table 1. Biochemical typing of Bt isolates.

\begin{tabular}{|c|c|c|c|c|c|c|c|c|}
\hline Isolate/Serial\# & Geographical Location/Crystal Shape & SAC & AMY & VP & CIT & OX & MOT & ADH \\
\hline Bt1 (284) & Al Hasa/Bi-pyramidal not attached & + & + & + & + & + & + & + \\
\hline Bt2 (319) & Hafr Al-Baten/Attached hexagonal & - & + & + & + & + & - & + \\
\hline Bt3 (594) & Yonbaa/Spherical & - & + & - & + & - & + & - \\
\hline Bt4 (605) & Al-Majma'ah/Spherical & + & + & - & - & + & + & + \\
\hline Bt5 (M300) & Mecca/Dark, bright, ovoid, Attached spore & + & + & + & + & + & + & + \\
\hline Bt6 (M268) & Al-Madina/Hexagonal-spore in chain & - & - & + & - & + & - & - \\
\hline Bt7 (M13m) & Asir/Small, outside, spherical, not attached & - & + & - & + & + & - & + \\
\hline Bt8 (M160) & Al-Majma'ah/Large bi-pyramidal, attached spore & - & - & + & - & + & - & - \\
\hline Bt9 (224) & Al Taif/Hexagonal, inclined spore & - & + & + & + & + & - & + \\
\hline
\end{tabular}

(SAC, sucrose; AMY, starch hydrolysis; VP, acetoin formation; CTA, citrate utilization; OX, oxidase; MOT, motility; $\mathrm{ADH}$, arginine dihydrolase).

\subsection{PCR Analysis of Bt Isolates}

Polymerase chain reaction (PCR) was performed on plasmid DNA to screen for the presence of selected Cry, Cyt and PS genes. Results of agarose gel electrophoresis revealed that were negative for all tested $\mathrm{Cry}$ and $\mathrm{Cyt}$ genes when compared to the reference strain Bti-H14, which was positive for all of them (Cry4A,Cry4B,Cry10,Cry11,Cyt1 and Cyt2). On the other hand, while the nine tested strains were negative for PS2, PS3 and PS4 genes, they exhibited positive amplification for target amplicon of the PS1 gene. As expected, the reference strain Bti-H14 exhibited no amplifications of the target products for all tested PS genes (Figure 3).

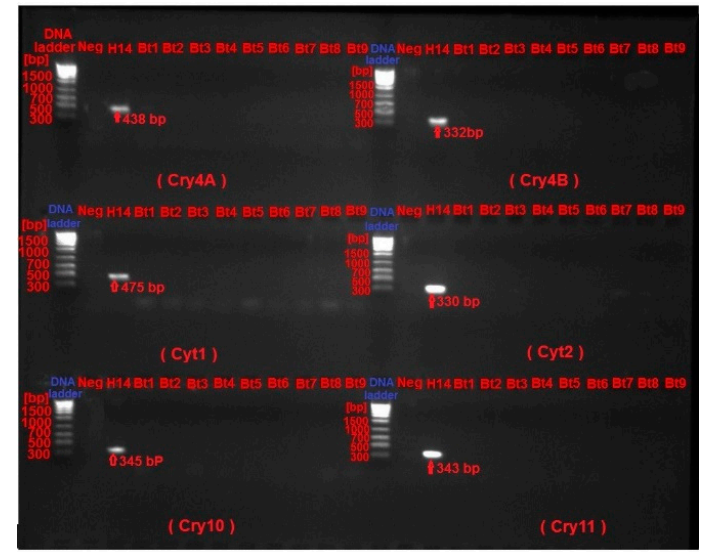

(A)

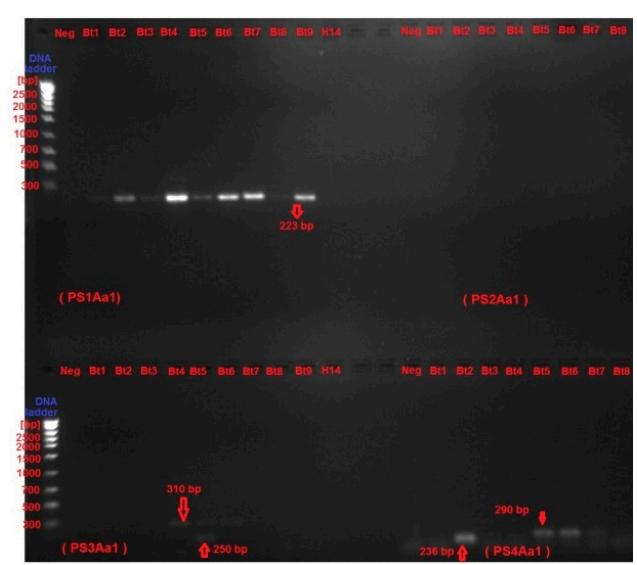

(B)

Figure 3. Polymerase chain reaction screening of Bt isolates for a panel of Cry, Cyt and PS genes. PCR reactions were conducted as described in Materials and Methods section. Amplicons were run at $100 \mathrm{v}$ for $30 \mathrm{~min}$ in $2 \%$ agarose gels pre-stained with ethidium bromide and examined with a charge-coupled device (CCD) camera mounted on a UVITC gel documentation system. Standard DNA marker was included in lane 1 to identify band sizes. (A) PCR of four Cry (4A, 4B, 10 and 11) Cyt (1 and 2) genes. All nine Bt strains were negative for these genes except the reference strain Bacillus thuringiensis subsp. israelensis (Bti-H14), which were positive for all tested Cry and Cty genes. (B) PCR for parasporin genes PS1, PS2, PS3 and PS4. All nine strains were positive for PS1 but negative for the rest. Neg., denotes negative control lane where deionized water was included instead of plasmid DNA template. 


\subsection{SDS-PAGE Analysis of Nascent and Trypsin-Activated PS Proteins}

SDS-PAGE of solubilized native and activated Bt parasporal crystal inclusions was conducted in order to examine PS banding pattern before and after activation (Figure 4). Silver-stained PS proteins that had been resolved onto $12 \%$ SDS-PAGE gel exhibited strain-specific protein banding profiles. For example, profile of nascent PS proteins from Bt5 showed bands at $155 \mathrm{kDa}, 140 \mathrm{kDa}, 82 \mathrm{kDa}$ and $41 \mathrm{kDa}$, whereas PS proteins from Bt7 showed bands at 83k Da, $68 \mathrm{kDa}, 64 \mathrm{kDa}, 32 \mathrm{kDa}, 25 \mathrm{kDa}$, $19 \mathrm{kDa}$ and $15 \mathrm{kDa}$ (Figure 4A). Upon trypsin activation, while PS proteins from Bt5 showed two bands at $41 \mathrm{kDa}$ and $16 \mathrm{kDa}$ (Figure 4B), PS proteins from Bt7 showed two bands at $56 \mathrm{kDa}$ and $16 \mathrm{kDa}$ (Figure 4C). Strains Bt1, 2, 3 and 4 exhibited identical protein profiles to Bt 5, whereas Bt8 and 9 exhibited profiles identical to Bt7.
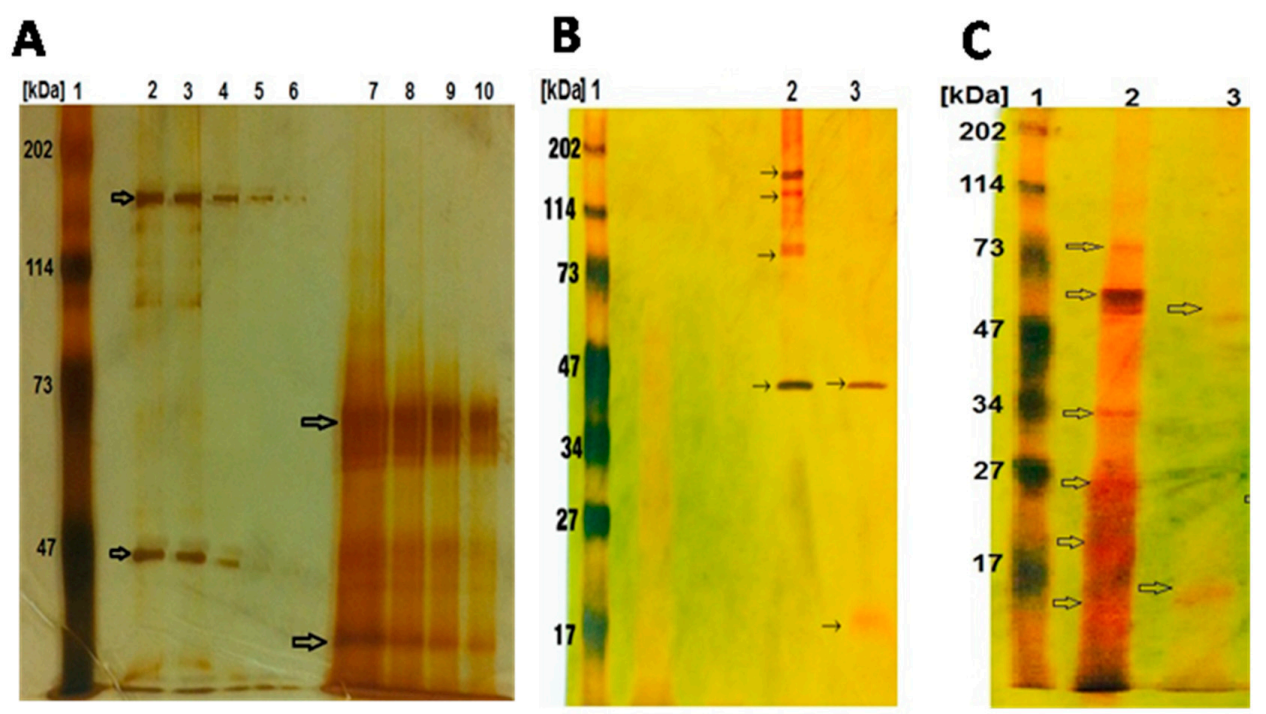

Figure 4. SDS-PAGE analysis of solubilized native and activated Bt parasporal crystal inclusions. PS proteins was resolved onto $12 \%$ SDS-PAGE gel and the bands were detected by silver staining, which was performed as detailed in the methods section. (A) Protein profiles of nascent PS proteins from Bt5 and Bt7. Lanes 2-6 were loaded with PS proteins from Bt5 at $10 \mu \mathrm{g}(2 \& 3), 3.6 \mu \mathrm{g}(4), 1.6 \mu \mathrm{g}(5)$ and $0.4 \mu \mathrm{g}$ (6); major bands at $155 \mathrm{kDa}$ and $41 \mathrm{kDa}$, and light bands at $140 \mathrm{kDa}, 114 \mathrm{kDa}$ and $105 \mathrm{kDa}$. PS proteins from Bt7 were loaded into lanes 7-10 at $10 \mu \mathrm{g}(7), 3.6 \mu \mathrm{g}(8), 1.6 \mu \mathrm{g}$ (9) and $0.4 \mu \mathrm{g}$ (10); major bands at $68 \mathrm{kDa}, 62 \mathrm{kDa}$ and $30 \mathrm{kDa}$, light bands at $43 \mathrm{kDa}, 39 \mathrm{kDa}$ and $37 \mathrm{kDa}$. (B) Protein profiles of nascent and activated PS proteins from Bt5. Lane 1, molecular marker; lane 2, loaded with $10 \mu \mathrm{g}$ native un-activated PS proteins with major bands at $155 \mathrm{kDa}, 140 \mathrm{kDa}, 82 \mathrm{kDa}$ and $41 \mathrm{kDa}$; lane 3, trypsinized PS proteins with major bands at $41 \mathrm{kDa}$ and $16 \mathrm{kDa}$. A trypsin-resistant band at molecular size of $41 \mathrm{kDa}$ is evident. (C) Protein profiles of nascent and activated PS proteins from Bt7. Lane 2, loaded with $9 \mu \mathrm{g}$ native un-activated PS proteins with major band at $68 \mathrm{kDa}$, and light bands at $83 \mathrm{kDa}$, $64 \mathrm{kDa}, 32 \mathrm{kDa}, 25 \mathrm{kDa}, 19 \mathrm{kDa}$ and $15 \mathrm{kDa}$; lane 3, loaded with $9 \mu \mathrm{g}$ trypsinized PS proteins with light bands at $56 \mathrm{kDa}$ and $16 \mathrm{kDa}$.

\subsection{Specific Anti-Proliferative Effects of PS Proteins}

Cytocidal activities of solubilized and trypsin-digested parasporal inclusion crystal proteins were assayed against cervical and colon cancer cells, viz., HeLa and HT-29, respectively, as judged by the observed cytopathic effect under phase contrast microscopy (data not shown). To this end, 3-[4,5-dimethylthiazol-2-yl]-2,5-diphenyltetrazoliumbromide (MTT) cytotoxicity data revealed differential and dose-dependent anti-proliferative effect only against HeLa but not HT-29 cells (Table 2). In this context, alkali-solubilized and trypsinized PS proteins at a concentration of $12.5 \mu \mathrm{g} / \mathrm{mL}$, which had been recovered from the nine Bt strains under investigation, resulted in significant proliferation inhibition rates against HeLa cells that ranged from 38 to $47 \%$, averaging $40 \%$, whereas, 
$\mathrm{IC}_{50}$ values ranged from $3.2(\mathrm{Bt} 1)$ to $14.2(\mathrm{Bt} 6)$ averaging $6.8 \mu \mathrm{g} / \mathrm{mL}$. The anticancer drug dasatinib exhibited inhibition and $\mathrm{IC}_{50}$ values of $58 \%$ and $24.4 \mu \mathrm{g} / \mathrm{mL}$, respectively. By contrast, HeLa cells exhibited minimal susceptibility against alkali-solubilized PS proteins in the absence trypsinization and upon heat denaturation $\left(94{ }^{\circ} \mathrm{C}\right.$ for $5 \mathrm{~min}$ ) of solubilized and proteolyzed PS proteins. The observed cytotoxicity of PS proteins against HeLa cells was specific as it was not evident against normal uterus smooth muscle cells (UtSMC).

Table 2. Cytotoxic activity of different alkali-solubilized and trypsinized parasporal crystal proteins against cancerous cell lines 24 -h post-treatment.

\begin{tabular}{ccccc}
\hline \multirow{2}{*}{ Bt isolate/Compound } & \multicolumn{2}{c}{ HeLa } & \multicolumn{2}{c}{ HT-29 } \\
\cline { 2 - 5 } & Inhibition $\mathbf{( \% )} *$ & IC $_{\mathbf{5 0}}{ }^{*}(\mu \mathrm{g} / \mathbf{m L})$ & Inhibition $^{*} \mathbf{( \% )}$ & IC $_{\mathbf{5 0}}(\boldsymbol{\mu g} / \mathbf{m L})$ \\
\hline Bt1 & 38 & 3.2 & 3 & nd $^{\text {a }}$ \\
Bt2 & 40 & 5.7 & 2 & nd \\
Bt4 & 35 & 5.4 & 0 & nd \\
Bt5 & 38 & 5.4 & 2 & nd \\
Bt6 & 40 & 9.5 & 3 & nd \\
Bt7 & 42 & 14.2 & 0 & nd \\
Bt8 & 47 & 5.6 & 0 & nd \\
Bt9 & 40 & 6.4 & 0 & nd \\
Dasatinib & 43 & 6.1 & 4 & nd \\
\hline
\end{tabular}

Inhibition (\%) ${ }^{*}$, Percentage of inhibition of cell proliferation at PS concentration of $12.5 \mu \mathrm{g} / \mathrm{mL}$, relative to $\mathrm{Na}_{2} \mathrm{CO}_{3}$ buffer control at equivalent serially-diluted concentration; ${ }^{\mathrm{IC}} \mathrm{C}_{50}$ values were calculated from the data of the cytotoxicity dose-response curve against HeLa cell line. nd a not determined. Dasatinib, is a positive control anticancer drug that acts as a potent multi-targeted kinase inhibitor of BCR-ABL and SRC family kinases.

\subsection{Transcriptional Activation of Apoptosis-Related Genes}

The effect of alkali-solubilized and proteolytically-activated PS proteins $(12.5 \mu \mathrm{g})$ from Bt5 on the transcriptional activity of two key apoptosis-related genes (i.e., caspase 3, CASP3; and caspase 9, CASP9) in HeLa cells was investigated by quantitative reverse transcription PCR (RT-qPCR) 24-h post-treatment (Figure 5). Results of RT-qPCR revealed a significant $(p<0.05)$ up-regulation in the level of expression for the two genes examined, in response to PS proteins, compared with $\mathrm{Na}_{2} \mathrm{CO}_{3}$ buffer control of identical dilution. Fold-change values of $3.7 \pm 0.26$ and $4.2 \pm 0.27$ were recorded for $h s C A S P 3$ and $h s C A S P 9$, respectively, as compared with the control.

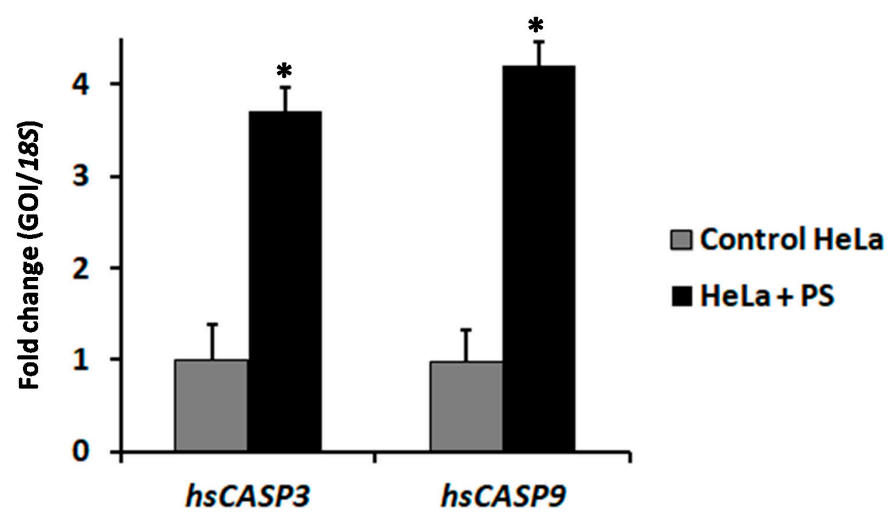

Figure 5. RT-qPCR analysis of apoptosis-related genes in HeLa cells. HeLa cells were treated for $24 \mathrm{~h}$ with $12.5 \mu \mathrm{g} / \mathrm{mL}$ of solubilized and activated PS proteins from Bt5. Expression profile was comparable with that obtained with Bt7. Relative expression was determined with the $2^{-\Delta \Delta \mathrm{Ct}}$ method using the PCR efficiencies determined with the standard curve included in each run. Each data point represents the results obtained from three independent batches of cDNA made. Expression of target genes (Gene of interest (GOI), $h_{S} C A S P 3$ and $h_{s} C A S P 9$ ) was normalized to that of the housekeeping gene $18 S$, represented as mean $\pm \mathrm{SD}$, and is expressed as fold-change. $\left(^{*}\right)$ indicates significantly different mean values at $p<0.05$ using a paired Student's $t$-test. 


\section{Discussion}

Cancers are among the most severe threats to human health due to the unsatisfactory efficacy and inevitable systemic toxicity of traditional radio- and chemo-therapies. Recently, several experimental cancer treatments have been presented as medical therapies intended to treat cancer by improving, supplementing or replacing conventional methods. These include photodynamic therapy, HAMLET (human alphalactalbumin made lethal to tumor cells) [29], gene therapy [30], telomerase inhibition therapy [31], Photothermal therapy via femtosecond-laser-excited nanoparticles [32], dichloroacetate (DCA) [33], non-invasive Kanzius radio frequency (RF) cancer treatment [34], complementary and alternative medicine (CAM) [35], nutritional therapy [36] and bacterial treatment [37]. But many of these therapies are controversial due to lack of efficacy, specificity and selectivity. In spite of the known limitations of these therapeutic strategies, cancer can be cured provided that it is diagnosed at early stages. In the quest for finding an alternative cure for cancer that is more effective and specific, our research group has collected a repository of $68 \mathrm{Bt}$ strains from 300 diverse environmental samples (October 2013-March 2014), isolated out of 16 sites across Saudi Arabia, and their potential larvicidal activity has previously been fully explored $[12,27,38]$. The present work represents the first report that examines the anticancer activity of nine non-larvicidal and non-hemolytic native Bacillus thuringiensis (Bt) isolates from different regions across Saudi Arabia.

The nine Bt strains were microscopically examined by both light and scanning electron microscopy, which confirmed the presence of the parasporal crystals of diverse morphologies, which conforms to previous findings [39]. Recently, it has been reported that PS proteins with non-insecticidal properties similarly exhibit variations in crystal morphology; which varies from spherical, bi-pyramidal to irregular [40]. The observed variation in crystal morphology correlate with the diversity of crystal proteins types in Bt isolates [9,41]. Moreover, the strains under investigation were molecularly confirmed to be Bacillus thuringienesis based on $99.5 \%$ homology to the reference strain Bti-H14, which is supported by our previous findings [28]. Analysis of PCR screening results indicated the absence of all the Cry and Cyt genes tested. This could be explained by the fact that all tested Bt isolates had previously been confirmed to be non-larvicidal and non-hemolytic; the two main characteristics generally found in Bt strains harboring PS proteins with anticancer activities [15,16]; which does not exclude the possibility that some PS proteins may be exhibiting insecticidal as well as anticancer activities [42]. The absence of Cyt proteins may explain the non-hemolytic nature of the tested Bt strains $[7,8]$. Moreover, PCR data concluded that Bt isolates harbor only the PS1 gene but not PS2, PS3 or PS4. Next, we attempted to group Bt isolates according to PS crystal protein(s) profile examined via SDS-PAGE. All the tested Bt isolates exhibited distinct nascent PS protein profiles from each other suggesting that the PS proteins could be different. Upon proteolytic cleavage, PS protein profiles exhibit patterns resembling those observed with PS1Aa1, with major bands at $56 \mathrm{kDa}$ and $17 \mathrm{kDa}(\mathrm{Bt} 7)$, and $41 \mathrm{kDa}$ and $16 \mathrm{kDa}(\mathrm{Bt5})$. PS1Aa1 protein isolated from strain Bt A1190 has been reported to have a molecular weight of $81 \mathrm{kDa}$ for the nascent form, which is cleaved into two forms comprising $56 \mathrm{kDa}$ and $15 \mathrm{kDa}$ polypeptides upon activation [16]. The observed variation between the activated PS protein profiles of our Bt strains and the standard PS1Aa1 might point to some novelty, which remains to be verified by PCR amplicon sequencing and N-terminal sequencing. All of our tested alkali-solubilized and trypsinized PS proteins from Bt strains exhibited potent and specific cytotoxicity against HeLa cell lines, which is in agreement with previous report implicating potency spectrum of activated PS1Aa1 not only against cervical cancer but also leukemic and hepatocarcinoma cells [16]. This observation clearly indicates a heterogeneous nature in the spectrum of cytotoxicity conveyed by PS1 proteins. PS1Aa1 is structurally categorized into the three-domain type of PS proteins that resembles three-domain Cry toxins in possessing highly conserved five-block sequences [43]; their nascent polypeptides are about $80 \mathrm{kDa}$ that are processed into $60-70 \mathrm{kDa}$ active forms. The three-domain type of PS proteins is not only confined to PS1 [16] but also extends to include PS3 [44] and PS6 [19].

The mechanism-of-action of PS1Aa1 in susceptible cells, such as HeLa, has been proposed to involve a rapid stimulation of calcium influx leading to a concomitant increase in intracellular calcium 
concentration culminating in the engagement of apoptotic signaling transduction pathway [45]. To this end, we have profiled the expression levels of two apoptosis-related marker genes, viz., capsase 3 ( $h s C A S P 3)$ and caspase 9 ( $h s C A S P 9)$ by RT-qPCR. The significant up-regulation in mRNA expression levels of $h_{s} C A S P 3$ and $h s C A S P 9$ genes supports the hypothesis that the observed susceptibility of HeLa cells towards PS proteins is mediated by activating the extrinsic apoptosis pathway. The intrinsic pathway is believed to be engaged at the cell surface via death receptor-mediated activation of either CASP9, or CASP8/CASP10 as the main initiators, leading to the activation CASP3 that is considered as an effector. It is noteworthy that once CASP3 is activated the apoptotic signaling cascade cannot be reversed or stopped [46].

\section{Materials and Methods}

\subsection{Ethical Approval}

The study was ethically approved by the Institutional Review Board of the College of Applied Medical Sciences, King Saud University (CAMS29/3334) on May 27th, 2013.

\subsection{Chemical and Supplies}

MTT (3-[4,5-dimethylthiazol-2yl]-2.5-diphenylterazolium bromide) was purchased from Sigma Aldrich (St Louis, MO, USA). DMEM, FBS, L-glutamine and penicillin/streptomycin were obtained from Hyclone Laboratories (Logan, UT, USA). Primers for 16s sequencing, PCR and RT-qPCR were ordered from Macrogen (Seoul, South Korea). Kits for cDNA reverse transcription and SYBR Green master mix were purchased from Qiagen (Hilden, Germany). All protein chemistry reagents and buffers were obtained from Bio-Rad Laboratories GmbH (Munich, Germany).

\subsection{Isolation, Culturing and Identification of $B$. Thuringiensis Isolates}

A total of sixty-eight B. thuringiensis (BT) isolates were obtained (October 2013-March 2014) from diverse environmental samples recovered from various locations in Saudi Arabia according to previously published protocols by our group. The full procedures of isolation, culturing and identification of Bt strains are detailed therein $[12,27,38]$.

\subsection{Biochemical and Molecular Typing}

Bt isolates were biochemically typed by use of API 20E systems (BioMerieux, Marcyle Etoile, France) according to the manufacturer's instructions. Readings were carried out in duplicate after $24 \mathrm{~h}$ and $48 \mathrm{~h}$ of incubation. The isolates were classified according to biochemical types based on hydrolysis of SAC, sucrose and AMY, starch hydrolysis; VP, acetoin formation; CTA, citrate utilization; OX, oxidase; MOT, motility; ADH, arginine dihydrolase; and urea hydrolysis. $16 \mathrm{~S}$ rDNA gene sequencing was conducted to confirm the genotype of the isolated strains as compared to the reference strains Bacillus thuringiensis subsp. israelensis (Bti-H14) and B. cereus (ATCC1177). Briefly, Bt isolates were sub-cultured on Luria Bertani (LB) agar and incubated at $30{ }^{\circ} \mathrm{C}$ overnight. After incubation, a single colony was suspended into $100 \mu \mathrm{L}$ sterile SDW water in an Eppendorf tube and placed in a shaking boiling water bath for $10 \mathrm{~min}$ followed by an immediate cooling shock at $-20{ }^{\circ} \mathrm{C}$. This heat-shock process was repeated three times to allow complete cell-lysis before centrifugation (Multifuge ${ }^{\mathrm{TM}}$ 3SR Plus centrifuge, Thermo Scientific, Germany) at 10,000 rpm for $10 \mathrm{~min}$ at $4{ }^{\circ} \mathrm{C}$. Template gDNA $(1 \mu \mathrm{L})$ was added in a $20 \mu \mathrm{L}$ PCR reaction comprising universal primers 27F(5'-AGAGTTTGATCCTGGCTCAG-3' /1492R(5'-TACGGTTACCTTGTTACGACTT-3'), and then a program of 35 amplification cycles $\left(94{ }^{\circ} \mathrm{C}\right.$ for $45 \mathrm{~s}, 55^{\circ} \mathrm{C}$ for $60 \mathrm{~s}$, and $72{ }^{\circ} \mathrm{C}$ for $60 \mathrm{~s}$ ) was performed. Amplicons of $\sim 1400 \mathrm{bp}$ were obtained and subsequently purified to remove unincorporated PCR primers and dNTPs from PCR products by use of Montage PCR Cleanup Kit (Millipore, Burlington, MA, USA). Sequencing was performed by using Big Dye terminator cycle sequencing Kit (Applied Biosystems, Foster City, CA, USA) based on Sanger dideoxy chain termination method [47]. Sequencing 
products were resolved on an Applied Biosystems model 3730XL automated DNA sequencing system (Applied Biosystems, USA). The obtained sequences were manually cleaned and edited by use of BioEdit Sequence Alignment Editor [48]. Database search for sequences of annotated genes corresponding to obtained rDNA sequences was carried out using the NCBI nucleotide Blast (http:/ /blast.ncbi.nlm.nih.gov).

\subsection{Scanning Electron Microscopy}

In order to obtain the spore-crystal mixture, Bt isolates were grown in nutrient agar medium for 5 days at $30^{\circ} \mathrm{C}$, until lysis. The spore-crystal mixtures were suspended in $1 \mathrm{~mL}$ of ice-cold $1 \mathrm{M} \mathrm{NaCl}$ and centrifuged for $5 \mathrm{~min}$ at $13,000 \times g$ then washed 3 times with cold sterile distilled water. The pellets were suspended in distilled water. Diluted suspensions of spore-crystal complexes were placed on cover glasses and air dried. Sample were then examined and photographed with a FEI-Inspect S50, scanning electron microscope operating at a voltage of $1500 \mathrm{kV}$ with $24,000 \times$ magnification [41].

\subsection{Cell Lines and Culture Conditions}

Two cancerous cell lines were utilized in this study, namely human cervical cancer (HeLa) and human colon adenocarcinoma (HT-29), were routinely maintained in DMEM (Dulbecco's modified Eagle medium) supplemented with 10\% FBS (Fetal Bovine Serum) and $2 \mathrm{mM}$ L-glutamine and $1 \%$ penicillin/streptomycin. The cells were kept in sterile Nunc ${ }^{\mathrm{TM}}$ cell culture treated polystyrene $75 \mathrm{~cm}^{2}$ flasks with vented filter cap (ThermoFisher Scientific ${ }^{\mathrm{TM}} \mathrm{GmbH}$, Karlsruhe, Germany), and sub-confluent cultures (70-80\%) were trypsinized (Trypsin 0.05\%/0.53 mM EDTA) and spilt depending on the seeding ratio. The cells were grown in a standard cell culture incubator at $37^{\circ} \mathrm{C}$ in $5 \% \mathrm{CO}_{2}$ humidified air.

\subsection{Hemolytic Assay}

Hemolytic activity of isolated PS proteins was determined against human erythrocytes (RBCs) according to standard procedures with some modifications [49]. Briefly, RBCs were washed three times in PBS and its concentration was adjusted to to $1 \times 10^{6}$ cells $/ \mathrm{mL}$. Then, $100 \mu \mathrm{g}$ of PS proteins was added per $1 \mathrm{~mL}$ RBCs and incubated for $18 \mathrm{~h}$ at $37^{\circ} \mathrm{C}$ followed by centrifugation at $1500 \times g$ for $10 \mathrm{~min}$. Finally, hemoglobin content in the resultant supernatant was measured at $570 \mathrm{~nm}$ by use of Shimadzu UV-1280 UV-VIS spectrophotometer (Nakagyo-ku, Kyoto, Japan).

\subsection{Crystal Sporal Mixture Isolation}

Bt isolates were inoculated to Modified Glucose Media (MGM) broth in separate flasks and incubated for $72 \mathrm{~h}$. The $\mathrm{pH}$ of the culture broth of each isolate was brought down to 7 using $1 \mathrm{~N}$ $\mathrm{HCl}$ and centrifuged at $8000 \mathrm{rpm}$ for $20 \mathrm{~min}$. The supernatant was discarded and the pellet was resuspended in $6 \%$ lactose at one-tenth volume of initial broth. The suspension was stirred for $30 \mathrm{~min}$ and four-volume acetone was slowly added followed by stirring for another $30 \mathrm{~min}$. Then, it was allowed to stand for $10 \mathrm{~min}$ at room temperature and filtered through Whatman No.1 filter paper. The acetone washing step was repeated thrice and finally the residue on the filter paper was allowed to dry overnight in a vacuum desiccator at room temperature. The white crystalline pellets were collected after drying and stored at $4{ }^{\circ} \mathrm{C}$ for further use [50].

\subsection{Solubilization and Activation of the Crude Parasporal Crystal Proteins}

The acetone powder containing crude PS proteins was suspended in $10 \mathrm{~mL}$ sterile deionized water (SDW) followed by centrifugation under cooling at $4000 \mathrm{rpm}$ for $20 \mathrm{~min}$. The pellet was then suspended in $3 \mathrm{~mL}$ SDW and washed twice with cold SDW via centrifugation. The washed pellet was then dissolved in $50 \mathrm{mM} \mathrm{Na}_{2} \mathrm{CO}_{3} / \mathrm{HCl}(\mathrm{pH}$ 10.5), containing $10 \mathrm{mM}$ dithiothreitol (DTT), EDTA $(1 \mathrm{mM})$ for $3 \mathrm{~h}$ in a shaking incubator at $37^{\circ} \mathrm{C}$, followed by centrifugation at $4000 \mathrm{rpm}$ for $50 \mathrm{~min}$ at 
$4{ }^{\circ} \mathrm{C}$. The resultant supernatant was subjected to $\mathrm{pH}$ adjustment to 8 with $1 \mathrm{~N} \mathrm{HCl}$, followed by protein determination [51] and stored at $-20^{\circ} \mathrm{C}$ until further use. For proteolytic activation, crude proteins $(1 \mathrm{mg} / \mathrm{mL})$ was treated with trypsin at a final concentration of $0.2 \mathrm{mg} / \mathrm{mL}$ for $3 \mathrm{~h}$ at $37^{\circ} \mathrm{C}$. This was followed by further centrifugation at $20,000 \times g$ for $5 \mathrm{~min}$ to remove the remaining insoluble materials. Phenylmethylsulfonyl fluoride (PMSF, Wako Pure Chemicals, Japan) was added to the solution at a final concentration of $1 \mathrm{mM}$ to stop the proteolytic reaction. The activated samples were sterilized by passing through $0.45 \mu \mathrm{m}$ sterile syringe filter (Nalgene, Thermo Scientific) and utilized for MTT cytotoxicity and protein assays.

\subsection{PCR Screening of Bt Isolates for Parasporin (PS) Genes}

Plasmids isolated from the nine Bt native isolates by alkali lysis method [41] were utilized for the screening of Cry, Cyt and PS genes using specific primers (Table 3). The $25 \mu \mathrm{L}$ PCR reaction mix comprised of $1 \mu \mathrm{L}$ (30 pg) plasmid DNA, $2.5 \mu \mathrm{L} 10 \times$ Taq buffer, $1 \mu \mathrm{L}$ dNTP mix $(10 \mathrm{mM}), 1 \mu \mathrm{L}$ forward primer (10 pmol), $1 \mu \mathrm{L}$ reverse primer $(10$ pmol), $2 \mu \mathrm{L}$ Taq DNA polymerase $(0.3 \mathrm{U} / \mu \mathrm{L})$ and $17.5 \mu \mathrm{L}$ sterile deionized water. Amplification was carried out in Applied Biosystems ${ }^{\circledR}$ Veriti $^{\circledR}$ 96-Well Thermal Cycler with the following 30-cycle temperature program: initial denaturation, $94{ }^{\circ} \mathrm{C}$ for $5 \mathrm{~min}$; denaturation, $94{ }^{\circ} \mathrm{C}$ for $1 \mathrm{~min}$; annealing (Table 3) 55/65 ${ }^{\circ} \mathrm{C} 1 \mathrm{~min}$; primer extension, $72{ }^{\circ} \mathrm{C}$ for $1 \mathrm{~min}$; final extension, $72{ }^{\circ} \mathrm{C}$ for $10 \mathrm{~min}$. PCR amplicons were resolved on $2 \%$ agarose, ethidium bromide-stained gel and subsequently visualized under the UV using by gel documentation system (UVITEC, Cambridge, UK). Plasmid DNA from Bacillus thuringiensis subsp. israelensis (Bti-H14) was included as a reference for comparison.

Table 3. Characteristics of general and specific primers employed for the detection of Cry, Cyt and PS genes.

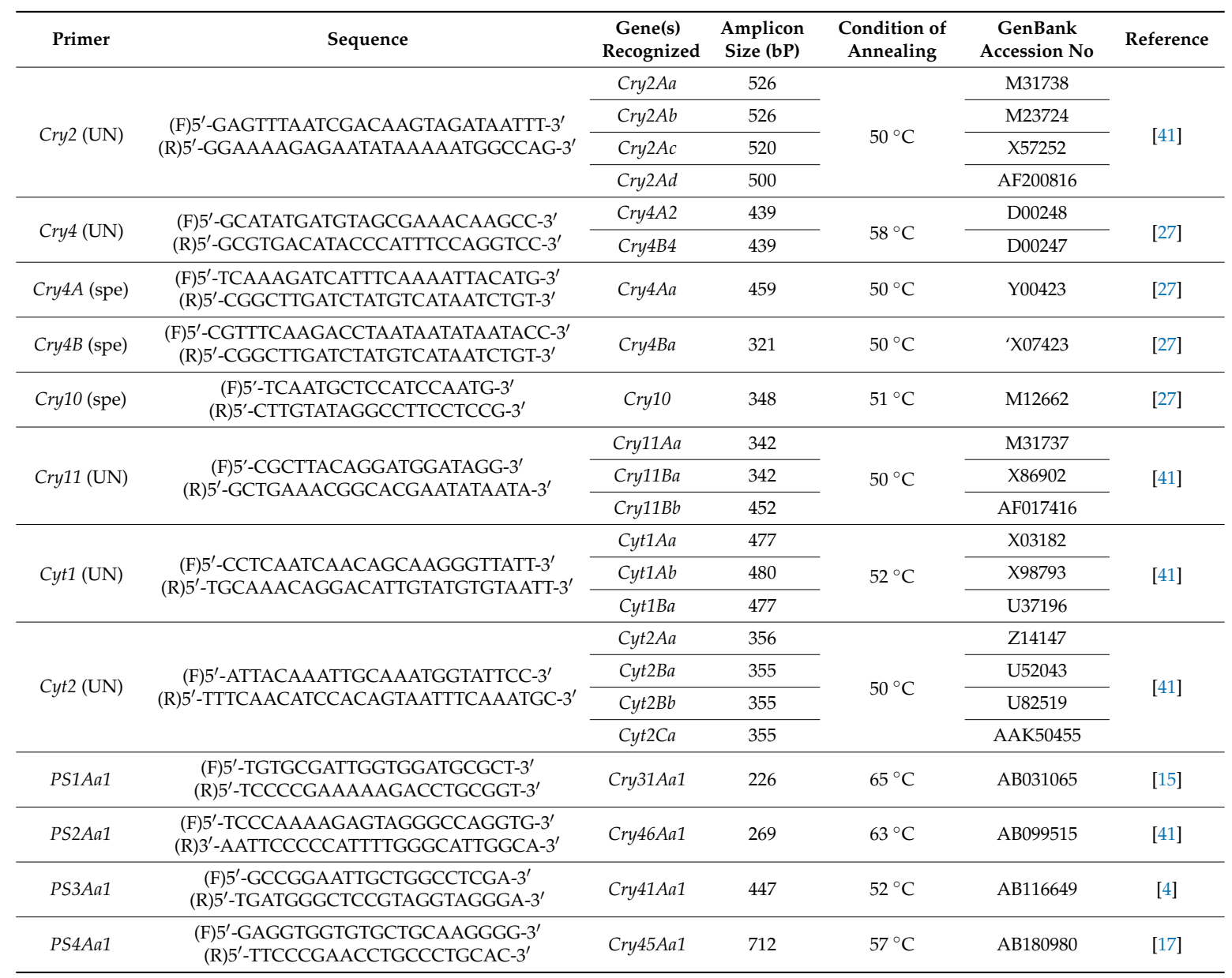




\subsection{Protein Chemistry}

PS proteins were solubilized at a concentration of $0.2 \mathrm{mg} / \mathrm{mL}$ in $50 \mathrm{mM} \mathrm{Na}_{2} \mathrm{CO}_{3} / \mathrm{HCl}(\mathrm{pH} 10.5)$ buffer containing $10 \mathrm{mM}$ DTT. Protein concentration of the samples was measured using bovine serum albumin (BSA) as a standard [51]. Nascent parasporal pro-toxins were activated with trypsin at $1: 10$ enzyme to PS inclusion ratio $(v / v)$ at $37^{\circ} \mathrm{C}$ for $3 \mathrm{~h}$ and activated. PS crystal proteins were resolved on $12 \%$ Sodium dodecyl sulfate-polyacrylamide gel electrophoresis (SDS-PAGE) gel [52] and the bands were detected by silver staining according to standard procedure [53]. Molecular weights were determined by use of protein standard (Protein marker II, 6.5-200 kDa; Appli-Chem GmbH, Darmstadt, Germany) comprising myosin (200 kDa), $\beta$-galactosidase (116.3 kDa), phosphoryase B $(97.4 \mathrm{kDa})$, bovine serum albumin $(66.2 \mathrm{kDa})$, ovalbumin $(45 \mathrm{kDa})$, and carbonic anhydrase $(31 \mathrm{kDa})$ soybean trypsin inhibitor (21.5 kDa), lysozyme (14.3 kDa) and aprotinin $(6.5 \mathrm{kDa})$.

\subsection{Measurement of Cellular Viability by MTT Assay}

The capability of the reducing enzymes that are present in viable cells to convert 3-[4,5-dimethylthiazol-2-yl]-2,5-diphenyltetrazoliumbromide (MTT) to formazan crystals was considered as a marker for measuring the cytotoxic potential of Bt-derived PS proteins against cancer cells according to previously described assay [54]. Briefly, cells cultured in complete medium were seeded into Thermo Scientific 96-Well Microtiter ${ }^{\mathrm{TM}}$ Microplates with $2 \times 10^{4}$ cells per well and incubated at $37{ }^{\circ} \mathrm{C}$ under a humidified atmosphere of $5 \% \mathrm{CO}_{2}$ for $24 \mathrm{~h}$. The cell medium in test wells were then changed to serum free medium (SFM) containing 2-fold serially-diluted, solubilized and trypsinized, and Millipore ${ }^{\mathrm{TM}}$-filtered $(0.45 \mu \mathrm{m})$ PS proteins with concentrations of $25,12.5,6.25,3.125,1.56$ and $0.78 \mu \mathrm{g} / \mathrm{mL}$, while the cell medium in control wells were changed to SFM containing an equivalent volume of sodium carbonate buffer. After incubation at $37^{\circ} \mathrm{C}$ under a humidified atmosphere of $5 \% \mathrm{CO}_{2}$ for $24 \mathrm{~h}$, cytopathic effects were observed under phase contrast microscopy. Then, SFM in control and test wells were replaced by $100 \mu \mathrm{L} /$ well of MTT, $0.5 \mathrm{mg} / \mathrm{mL}$ ) in Phosphate-Buffered saline (PBS) and incubated at $37^{\circ} \mathrm{C}$ for further $3 \mathrm{~h}$. Then, MTT was aspirated and the purple formazan crystals formed at the bottom of the wells were dissolved using $100 \mu \mathrm{L}$ isopropyl alcohol/well with shaking for $1 \mathrm{~h}$ at room temperature in the dark. The absorbance at $549 \mathrm{~nm}$ was read on a microplate reader (ELX 800; Bio-Tek Instruments, Winooski, VT, USA). PS protein concentrations causing 50\% cell growth inhibition ( $\mathrm{IC}_{50}$ ) were calculated for each $\mathrm{BT}$ strain. The cytotoxic of the anticancer drug dasatinib, a potent multi-targeted kinase inhibitor of BCR-ABL and SRC family kinases [55], against the two cell lines was examined at the same concentrations of tested compounds and utilized as a standard positive control for comparative purposes.

\subsection{Gene Expression Profiling of Apoptotic Genes by Quantitative Reverse Transcriptase Polymerase Chain Reaction (RT-qPCR)}

Total RNA was extracted from HeLa cells, 24-h post-treatment with $12.5 \mu \mathrm{g}$ of activated PS proteins isolated from Bt5, using Total RNA Purification Kit (Norgen Biotek Corp., Thorold, ON, Canada) according to the manufacturer's instructions. RNA quality was assessed from the ratio $\lambda_{260} / \lambda_{280}$ by measuring the absorption at $260 \mathrm{~nm}$ and $280 \mathrm{~nm}$ (protein contamination) using Qubit ${ }^{\circledR 2.0}$ Fluorometer and NanoDrop ${ }^{\mathrm{TM}}$ One ${ }^{\mathrm{C}}$ Microvolume UV-Vis spectrophotometer (ThermoFisher Scientific ${ }^{\mathrm{TM}} \mathrm{GmbH}$, Karlsruhe, Germany); ratios were always $>1.8$. Genomic DNA was then eliminated and cDNA synthesized from RNA $(1 \mu \mathrm{g})$ in a final reaction volume $(20 \mu \mathrm{L})$ using the QuantiTect Reverse Transcriptase Kit (Qiagen, Germany). RT-qPCR was subsequently performed on a Rotor-Gene Q 5-Plex HRM thermal cycler (Qiagen, Germany) as previously described [40], using a QuantiTect SYBR-Green PCR Kit (Qiagen, Germany), with the following primer assays for apoptosis-related cysteine peptidase marker genes: Hs_CASP3_1_SG QuantiTect Primer Assay (QT00023947) and Hs_CASP9_1_SG QuantiTect Primer Assay (QT00036267) in a final reaction volume $(25 \mu \mathrm{L})$ containing the diluted cDNA sample $(5 \mu \mathrm{L}), 2 x$ SYRB-Green PCR Master Mix $(12.5 \mu \mathrm{L})$, each forward and reverse primer (10 $\mu \mathrm{M}$ stock, $2.5 \mu \mathrm{L})$ and RNase-free water $(2.5 \mu \mathrm{L})$. The amplification program and PCR amplicon specificity were 
performed and assessed as previously documented [40]. Each sample was represented by 2 biological replicas and three technical replicas, with the inclusion of a no-template control. Raw data were analyzed using the Rotor-Gene ${ }^{\circledR}$ cycler software 2.1 (Qiagen $\mathrm{GmbH}$, Düsseldorf, Germany) to calculate the threshold cycle $(\mathrm{Ct})$ using the second derivative maximum. The fold-change value for each gene was determined after normalization to the expression levels of $18 \mathrm{~S}$ as a housekeeping gene which was calculated using the equation $2^{-\Delta \Delta C t}[56]$.

\subsection{Statistical Analysis}

The calculations and statistical analysis were carried out using the Statistical Package for Social Sciences (SPSS; IL, USA) for Windows version 17.0. All data were represented as mean \pm standard deviation (SD) 3 individual experiments each in duplicate. The relative gene expression data were subjected to paired Student's $t$-test in order to identify significant differences between PS- and $\mathrm{Na}_{2} \mathrm{CO}_{3}$-treated cells at equivalent dilution rate. Treatments were considered statistically significant at $p<0.05$.

Author Contributions: Conceptualization, M.A.M.A.-S., Y.A.A.-S. and T.A.E.-K.; methodology, M.A.M.A.-S., M.Z.A.-A., A.K. and T.A.E.-K.; validation, M.A.M.A.-S. and T.A.E.-K.; formal analysis, T.A.E.-K., M.A.M.A.-S. and A.E.A.; investigation, M.A.M.A.-S., A.K. and M.Z.A.-A.; resources, Y.A.A.-S., M.A.M.A.-S.; writing-original draft preparation, M.A.M.A.-S.; writing-review and editing, M.A.M.A.-S. and T.A.E.-K.; visualization, T.A.E.-K. and M.A.M.A.-S.; project administration, M.A.M.A.-S.; funding acquisition, Y.A.A.-S.

Funding: This study was financially supported by King Saud University, Vice Deanship of Research Chairs.

Acknowledgments: This study was financially supported by King Saud University, Vice Deanship of Research Chairs.

Conflicts of Interest: The authors declare no conflicts of interest. The funders had no role in the design of the study; in the collection, analyses, or interpretation of data; in the writing of the manuscript, or in the decision to publish the results.

\section{References}

1. The International Agency for Research on Cancer (IARC), Global Cancer Observatory, World Health Organization (WHO). Report on the Latest Estimates on the Global Burden of Cancer. Date of Release: 12 September 2018 in Geneva, Switzerland. Available online: https:/ /www.iarc.fr/wp-content/uploads/2018/ 09/pr263_E.pdf (accessed on 13 December 2018).

2. Bazarbashi, S.; Al Eid, H.; Minguet, J. Cancer Incidence in Saudi Arabia: 2012 Data from the Saudi Cancer Registry. Asian Pac. J. Cancer Prev. 2017, 18, 2437-2444. [PubMed]

3. Ibrahim, E.M.; Zeeneldin, A.A.; El-Khodary, T.R.; Al-Gahmi, A.M.; Bin Sadiq, B.M. Past, Present and Future of Colorectal Cancer in the Kingdom of Saudi Arabia. Saudi J. Gastroenterol. 2008, 14, 178-182. [CrossRef] [PubMed]

4. Are, C.; Rajaram, S.; Are, M.; Raj, H.; Anderson, B.O.; Chaluvarya Swamy, R.; Vijayakumar, M.; Song, T.; Pandey, M.; Edney, J.A.; et al. A review of global cancer burden: Trends, challenges, strategies, and a role for surgeons. J. Surg. Oncol. 2013, 107, 221-226. [CrossRef]

5. Cancer Council Australia. Understanding Chemotherapy: A Guide for People with Cancer, Their Families and Friends; Cancer Council Australia: Woolloomooloo, Australia, 2016; ISBN 9781925136180.

6. Palma, L.; Muñoz, D.; Berry, C.; Murillo, J.; Caballero, P. Bacillus thuringiensis toxins: An overview of their biocidal activity. Toxins (Basel) 2014, 6, 3296-3325. [CrossRef] [PubMed]

7. Bravo, A.; Likitvivatanavong, S.; Gill, S.S.; Soberón, M. Bacillus thuringiensis: A story of a successful bioinsecticide. Insect Biochem. Mol. Biol. 2011, 41, 423-431. [CrossRef] [PubMed]

8. Crickmore, N.; Zeigler, D.R.; Feitelson, J.; Schnepf, E.; Van Rie, J.; Lereclus, D.; Baum, J.; Dean, D. Revision of the nomenclature for the Bacillus thuringiensis pesticidal crystal proteins. Microbiol. Mol. Biol. Rev. 1998, 62, 807-813. [PubMed]

9. Schnepf, E.; Crickmore, N.; Van Rie, J.; Lereclus, D.; Baum, J.; Feitelson, J.; Zeigler, D.R.; Dean, D.H. Bacillus thuringiensis and its pesticidal crystal proteins. Microbiol. Mol. Biol. Rev. 1998, 62, 775-806. [PubMed]

10. Vachon, V.; Laprade, R.; Schwartz, J.-L. Current models of the mode of action of Bacillus thuringiensis insecticidal crystal proteins: A critical review. J. Invertebr. Pathol. 2012, 111, 1-12. [CrossRef] [PubMed] 
11. Hofte, H.; Whiteley, H.R. Insecticidal crystal proteins of Bacillus thuringiensis. Microbiol. Rev. 1989, 53, 242-255. [PubMed]

12. El-Kersh, T.A.; Al-sheikh, Y.A.; Al-Akeel, R.; Alsayed, A.A. Isolation and characterization of indigenous Bacillus thuringiensis isolates from Saudi Arabia. Afr. J. Biotechnol. 2012, 11, 1924-1938.

13. Ohba, M.; Mizuki, E.; Uemori, A. Parasporin, a new anticancer protein group from Bacillus thuringiensis. Anticancer Res. 2009, 29, 427-433. [PubMed]

14. Mizuki, E.; Ohba, M.; Akao, T.; Yamashita, S.; Saitoh, H.; Park, Y.S. Unique activity associated with non-insecticidal Bacillus thuringiensis parasporal inclusions: In vitro cell-killing action on human cancer cells. J. Appl. Microbiol. 1999, 86, 477-486. [CrossRef] [PubMed]

15. Mizuki, E.; Park, Y.S.; Saitoh, H.; Yamashita, S.; Akao, T.; Higuchi, K.; Ohba, M. Parasporin, a human leukemic cell-recognizing parasporal protein of Bacillus thuringiensis. Clin. Diagn. Lab. Immunol. 2000, 7, 625-634. [CrossRef] [PubMed]

16. Katayama, H.; Yokota, H.; Akao, T.; Nakamura, O.; Ohba, M.; Mekada, E.; Mizuki, E. Parasporin-1, a novel cytotoxic protein to human cells from non-insecticidal parasporal inclusions of Bacillus thuringiensis. J. Biochem. 2005, 137, 17-25. [CrossRef] [PubMed]

17. Saitoh, H.; Okumura, S.; Ishikawa, T.; Akao, T.; Mizuki, E.; Ohba, M. Investigation of a novel Bacillus thuringiensis gene encoding a parasporal protein, parasporin-4, that preferentially kills human cancer cells. Biosci. Biotechnol. Biochem. 2006, 70, 2935-2971. [CrossRef] [PubMed]

18. Okumura, S.; Ohba, M.; Mizuki, E.; Crickmore, N.; Côté, J.-C.; Nagamatsu, Y.; Kitada, S.; Sakai, H.; Harata, K.; Shin, T. Parasporin Nomenclature. 2010. Available online: http:/ / parasporin.fitc.pref.fukuoka.jp/ (accessed on 1 April 2013).

19. Nagamatsu, Y.; Okamura, S.; Saitou, H.; Akao, T.; Mizuki, E. Three Cry toxins in two types from Bacillus thuringiensis strain M019 preferentially kill human hepatocyte cancer and uterus cervix cancer cells. Biosci. Biotechnol. Biochem. 2010, 74, 494-498. [CrossRef]

20. Hire, R.S.; Makde, R.D.; Dongre, T.K.; D'Souza, S.F. Characterization of the cry1Ac17 gene from an indigenous strain of Bacillus thuringiensis subsp. kenyae. Curr. Microbiol. 2008, 57, 570-574. [CrossRef]

21. Liang, H.; Liu, Y.; Zhu, J.; Guan, P.; Li, S.; Wang, S.; Zheng, A.; Liu, H.; Li, P. Characterization of cry2-type genes of Bacillus thuringiensis strains from soilisolated of Sichuan Basin, China. Braz. J. Microbiol. 2011, 42, 140-146. [CrossRef]

22. Lakxmy, A.P.; Xavier, R.; Reenajosephine, C.M.; Lee, Y.W.; Marimuthu, K.; Kathiresan, S.; Sreeramanan, S. Mosquitocidal activity of a native Bacillus thuringiensis isolate Bt ReX02 from Gunung Jerai forest, Malaysia against Culex quinquefasciatus and Aedes albopictus. Eur. Rev. Med. Pharmacol. Sci. 2011, 15, 149-155.

23. Lee, D.-W.; Akao, T.; Yamashita, S.; Katayama, H.; Maeda, M.; Saitoh, H.; Mizuki, E.; Ohba, M. Noninsecticidal parasporal proteins of a Bacillus thuringiensis serovar shandongiensis isolate exhibit a preferential cytotoxicity against human leukemic T cells. Biochem. Biophys. Res. Commun. 2000, 272, 218-223. [CrossRef]

24. Nadarajah, V.D.; Ting, D.; Chan, K.K.; Mohamed, S.M.; Kanakeswary, K.; Lee, H.L. Selective cytotoxic activity against leukemic cell lines from mosquitocidal Bacillus thuringiensis parasporal inclusions. Southeast Asian J. Trop. Med. Public Health 2008, 39, 235-245. [PubMed]

25. Poornima, K.; Saranya, V.; Abirami, P.; Binuramesh, C.; Suguna, P.; Selvanayagam, P.; Shenbagarathai, R. Phenotypic and genotypic characterization of B.t.LDC-391 strain that produce cytocidal proteins against human cancer cells. Bioinformation 2012, 8, 461-465. [CrossRef] [PubMed]

26. Chubicka, T.; Girija, D.; Deepa, K.; Salini, S.; Meera, N.; Raghavamenon, A.C.; Divya, M.K.; Babu, T.D. A parasporin from Bacillus thuringiensis native to Peninsular India induces apoptosis in cancer cells through intrinsic pathway. J. Biosci. 2018, 43, 407-416. [CrossRef] [PubMed]

27. El-kersh, T.A.; Al-akeel, R.A.; Al-sheikh, Y.A.; Alharbi, S.A. Isolation and distribution of mosquito-larvicidal cry genes in Bacillus thuringiensis strains native to Saudi Arabia. Trop. Biomed. 2014, 31, 616-632. [PubMed]

28. El-Kersh, T.A.; Ahmed, A.M.; Al-Sheikh, Y.A.; Tripet, F.; Ibrahim, M.S.; Metwalli, A.A. Isolation and characterization of native Bacillus thuringiensis strains from Saudi Arabia with enhanced larvicidal toxicity against the mosquito vector Anopheles gambiae (s.1.). Parasit Vectors 2016, 9, 647. [CrossRef] [PubMed]

29. Svanborg, C.; Agerstam, H.; Aronson, A.; Bjerkvig, R.; Duringer, C.; Fischer, W.; Gustafsson, L.; Hallgren, O.; Leijonhuvud, I.; Linse, S.; et al. HAMLET kills tumor cells by an apoptosis-like mechanism-cellular, molecular, and therapeutic aspects. Adv. Cancer Res. 2003, 88, 1-29. [PubMed] 
30. Jia, L.-T.; Chen, S.Y.; Yang, A.-G. Cancer gene therapy targeting cellular apoptosis machinery. Cancer Treat. Rev. 2012, 38, 868-876. [CrossRef] [PubMed]

31. Ruden, M.; Puri, N. Novel anticancer therapeutics targeting telomerase. Cancer Treat. Rev. 2013, 39, 444-456. [CrossRef]

32. Chen, C.-C.; Chang, F.-H.; Lin, K.-H.; Tsai, D.-H.; Chen, Y.-Y. Photothermal cancer therapy via femtosecondlaser-excited FePt nanoparticles. Biomaterials 2013, 34, 1128-1134. [CrossRef]

33. Kumar, A.; Kant, S.; Singh, S.M. Novel molecular mechanisms of antitumor action of dichloroacetate against T cell lymphoma: Implication of altered glucose metabolism, $\mathrm{pH}$ homeostasis and cell survival regulation. Chem. Biol. Interact. 2012, 199, 29-37. [CrossRef]

34. Glazer, E.S.; Massey, K.L.; Zhu, C.; Curley, S.A. Pancreatic carcinoma cells are susceptible to noninvasive radio frequency fields after treatment with targeted gold nanoparticles. Surgery 2010, 148, 319-324. [CrossRef] [PubMed]

35. Ben-Arye, E.; Lev, E.; Schiff, E. Complementary Medicine Oncology Research in the Middle-East: Shifting from Traditional to Integrative Cancer Care. Eur. J. Integr. Med. 2011, 3, 29-37. [CrossRef]

36. Hussain, S.S.; Kumar, A.P.; Ghosh, R. Food-based natural products for cancer management: Is the whole greater than the sum of the parts? Semin. Cancer Biol. 2016, 40-41, 233-246. [CrossRef] [PubMed]

37. Patyar, S.; Joshi, R.; Prasad Byrav, D.S.; Prakash, A.; Medhi, B.; Das, B.K. Bacteria in cancer therapy: A novel experimental strategy. J. Biomed. Sci. 2010, 17, 21-29. [CrossRef] [PubMed]

38. Ahmed, A.M.; Hussein, H.I.; El-Kersh, T.A.; Al-Sheikh, Y.A.; Ayaad, T.H.; El-Sadawy, H.A.; Al-Mekhlafi, F.A.; Ibrahim, M.S.; Al-Tamimi, J.; Nasr, F.A. Larvicidal activities of indigenous Bacillus thuringiensis isolates and nematode symbiotic bacterial toxins against the mosquito vector, Culex pipiens (Diptera: Culicidae). J. Arthropod-Borne Dis. 2017, 11, 260-277. [PubMed]

39. Martin, P.A.; Gundersen-Rindal, D.E.; Blackburn, M.B. Distribution of phenotypes among Bacillus thuringiensis strains. Syst. Appl. Microbiol. 2010, 33, 204-208. [CrossRef] [PubMed]

40. Ito, A.; Sasaguri, Y.; Kitada, S.; Kusakar, Y.; Kuwano, K.; Masutomi, K.; Mizuki, E.; Akao, T.; Ohba, M. A Bacillus thuringiensis crystal protein with selective cytocidal action to human cells. J. Biol. Chem. 2004, 279, 21282-21286. [CrossRef] [PubMed]

41. Ibarra, J.E.; del Rincon, M.C.; Orduz, S.; Noriega, D.; Benintende, G.; Monnerat, R.; Regis, L.; de Oliveira, C.M.; Lanz, H.; Rodriguez, M.H.; et al. Diversity of Bacillus thuringiensis strains from Latin America with insecticidal activity against different mosquito species. Appl. Environ. Microbiol. 2003, 69, 5269-5274. [CrossRef] [PubMed]

42. Akiba, T.; Okumura, S. Parasporins 1 and 2: Their structure and activity. J. Invertebr. Pathol. 2017, 142, 44-49. [CrossRef]

43. de Maagd, R.A.; Bravo, A.; Berry, C.; Crickmore, N.; Schnepf, H.E. Structure, diversity, and evolution of protein toxins from spore-forming entomopathogenic bacteria. Annu. Rev. Genet. 2003, 37, 409-433. [CrossRef]

44. Yamashita, S.; Katayama, H.; Saitoh, H.; Akao, T.; Park, Y.S.; Mizuki, E.; Ohba, M.; Ito, A. Typical Three-Domain Cry Proteins of Bacillus thuringiensis Strain A1462 Exhibit Cytocidal Activity on Limited Human Cancer Cells. J. Biochem. 2005, 138, 663-672. [CrossRef]

45. Katayama, H.; Kusaka, Y.; Yokota, H.; Akao, T.; Kojima, M.; Nakamura, O.; Mekada, E.; Mizuki, E. Parasporin-1, a novel cytotoxic protein from Bacillus thuringiensis, induces $\mathrm{Ca}^{2+}$ influx and a sustained elevation of the cytoplasmic $\mathrm{Ca}^{2+}$ concentration in toxin-sensitive cells. J. Biol. Chem. 2007, 282, 7742-7752. [CrossRef] [PubMed]

46. Green, D.R.; Amarante-Mendes, G.P. The point-of-no-return: Mitochondria, caspases and the commitment to cell death. Results Probl. Cell Differ. 1998, 24, 45-61. [PubMed]

47. Sanger, F.; Nicklem, S.; Coulso, N.A. DNA sequencing using chain termination inhibitors. Proc. Natl. Acad. Sci. USA 1977, 74, 5463-5467. [CrossRef] [PubMed]

48. Hall, T. BioEdit: A user-friendly biological sequence alignment editor and analysis program for Windows 95/98/NT. Nucleic Acids Symp. 1999, 41, 95-98.

49. Yu, Y.M.; Ohba, M.; Gill, S.S. Characterization of mosquitocidal activity of Bacillus thuringiensis subsp fukuokaensis crystal proteins. Appl. Environ. Microbiol. 1991, 57, 1075-1081. [PubMed]

50. Nethravathi, C.J.; Hugar, P.S.; Krishnaraj, P.U.; Vastrad, A.S.; Awaknavar, J.S. Bioefficacy of crude protein of native Bacillus thuringiensis (Berliner) isolates against cabbage leaf. Karnataka J. Agric. Sci. 2009, 22, 613-616.

51. Lowry, O.H.; Rosebrough, N.J.; Farr, A.L.; Randall, R.J. Protein measurement with the Folin phenol reagent. J. Biol. Chem. 1951, 193, 265-275. 
52. Laemmli, U.K. Cleavage of structural proteins during the assembly of the head of bacteriophage T4. Nature 1970, 227, 680-685. [CrossRef]

53. Blum, H.; Beier, H.; Gross, H.J. Improved method for silver staining of plant proteins, RNA and DNA in polyacrylamide gels. Electrophoresis 1987, 8, 93-99. [CrossRef]

54. Kohle, C.; Badary, O.A.; Nill, K.; Bock-Hennig, B.S.; Bock, K.W. Serotonin glucuronidation by Ah receptor- and oxidative stress-inducible human UDP-glucuronosyltransferase (UGT) 1A6 in Caco-2 cells. Biochem. Pharmacol. 2005, 69, 1397-1402. [CrossRef] [PubMed]

55. Lombardo, L.J.; Lee, F.Y.; Chen, P.; Norris, D.; Barrish, J.C.; Behnia, K.; Castaneda, S.; Cornelius, L.A.; Das, J.; Doweyko, A.; et al. Discovery of N-(2-chloro-6-methyl-phenyl)-2-(6-(4-(2-hydroxyethyl)-piperazin-1-yl)-2methylpyrimidin-4-ylamino)thiazole-5-carboxamide (BMS-354825), a dual Src/Abl kinase inhibitor with potent antitumor activity in preclinical assays. J. Med. Chem. 2004, 47, 6658-6661. [CrossRef] [PubMed]

56. Al-Sheikh, Y.A.; Ghneim, H.K.; Softa, K.I.; Al-Jobran, A.A.; Al-Obeed, O.; Mohamed, M.A.; Abdulla, M.; Aboul-Soud, M.A. Expression profiling of selected microRNA signatures in plasma and tissues of Saudi colorectal cancer patients by qPCR. Oncol. Lett. 2016, 11, 1406-1412. [CrossRef] [PubMed]

Sample Availability: Samples of the compounds are not available from the authors. 